\title{
Business Ethics Education: One Management Educator's Perspective
}

\author{
Nancy J. Niles, (E-mail: nilesn@ concord.edu ), Concord University
}

\begin{abstract}
Results from the 2005 National Business Ethics Survey (NBES) indicate that over half of employees observed at least one type of misconduct in the workplace during the past 12 months, with nearly $40 \%$ observing two or more violations (http://www.ethics.org). The President of the Ethics Resource Center, Dr. Patricia Harned, has stated that this statistic has not changed much over the past 5 years even though there is a rise in the number of companies that have implemented ethics programs (http://www.ethics.org) Business faculty has the opportunity to provide business students with ethical reasoning opportunities to meet these ethical challenges successfully. AACSB has stated in their 2004 Ethics Education in Business Schools that...business education must encourage students to develop an understanding of the challenges surrounding business ethics and provide students with the tools to recognize and respond to ethical issues, both personally and organizationally (9). This paper outlines a proposed undergraduate business ethics education model that is developed in compliance with AACSB standards.
\end{abstract}

\section{ONE MANAGEMENT EDUCATOR'S EFFORTS}

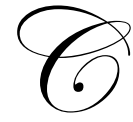

oncord University, a small educational institution located in Athens, West Virginia, recently submitted their initial 5-year plan for AACSB accreditation. As part of its accreditation plan of action, the Business Ethics course, which was a business elective, has become a core curriculum course, effective fall semester 2005. The learning goal of the course is to present concepts that students will be able to apply to the business world when presented with some difficult ethical dilemmas (Ethics Education Report, 2004). The author also focused on three AACSB standards: 13-Individual Faculty Responsibility, 14-Student Educational Responsibility and 15-the Assurance of Learning standard. For standards 13 and 14, the instructor developed an anonymous survey distributed to both faculty and students to asses their expectations of themselves and each other. For standard 15, management of curricula- assurance of learning, she utilized several course-embedded exercises as well as the use of assessment of learning rubrics for ethical awareness.

Additionally, the author implemented a survey to assess: 1) the Division of Business' efforts to discuss ethics across the curriculum and 2) the students' belief of the effect of business ethics education on their future behavior in the business world. This paper discusses the business ethics course outline, how it pertains to AACSB standards and business students' attitudes towards business ethics education.

\section{INTRODUCTION}

The business ethics course has been an elective course in the Division of Business at Concord University for several years. The course is located in the management area of emphasis and is considered an upper level management course. Based on discussions with the University's AACSB mentor, the Division of Business decided to place the business ethics course into the business core component effective, fall semester 2005. The course focuses on the discussion of business ethics using the stakeholder management theory which states that there are several stakeholders' interests, both internal and external to the organization that a firm must satisfy. (Freeman, 1984) Internal stakeholders such as employees, owners and shareholder concerns must be considered. External stakeholders such as the consumers or customers, the community and special interest groups also have concerns that must be satisfied (Freeman, 1984). Depending on the current situation of the firm, the power of the stakeholders may vary. 
Because a firm attempts to satisfy all of their stakeholders needs, conflicts may arise. When these conflicts arise, unethical decision-making may result because firms are trying to satisfy all of their stakeholders

(Mitchell, Angle and Wood, 1997).

\section{LEARNING GOAL OF BUSINESS ETHICS COURSE}

The learning goal of business ethics education is to present concepts that students will be able to apply to the business world when presented with some difficult ethical dilemmas. Each student will be able to recognize and analyze ethical issues in the workplace and apply these skills to their own actions (Ethics Education Report, 2004).

\section{TEXT SELECTION}

\section{Managerial Approach To Business And Society}

There is a plethora of business ethics textbooks. The author wanted to select a text that provides an undergraduate an overview of the different theories of ethical decision making. As a management educator, the author wanted a text that also focuses on the difficulty managers may have during the decision making process as a result of pressure from both external and internal sources. The author selected Business and Society: Ethics and Stakeholder Management by Carroll and Buchholz (6e). This text takes a managerial approach to the relationship between business and society, emphasizing business ethics and stakeholder management. According to Carroll and Bucholz, the manager must address the following questions:

- What societal pressures exist that require a business to become proactive to these pressures?

- Is the business responsible for creating these problems?

- What environmental changes are impacting the company?

- What type of issues management should we develop to respond to social issues? (22)

While attempting to answer these questions, the groups or stakeholders that interact with the business must also be considered. The book focuses on the primary internal stakeholders who consist of the business owners and employers and the primary external stakeholders who include the community, government and the customers. The text is divided into 5 components: 1) corporate social responsibility 2) strategic management 3) managing business ethics, 4) external stakeholder issues and 5) internal stakeholder issues (24).

The textbook also discusses several different approaches to making business ethical decision. The conventional approach to ethics compares an action with the current industry norm. The principles approach depends on managers making decisions based on what is right, just and fair to others and the consequences of these actions or if an action taken is the duty of a manager. The tests approach asks a manager to test themselves in several ways to assess if an action will be ethical $(175,218,225)$.

Managers make several decisions as part of their routine work day. Often, their decisions are influenced by different stakeholder wants or needs. Different pressures may force a manger to make a decision that may conflict with personal or organizational ethics. This text provides the framework for management students to realize that there may be a time in their careers when they are faced with some difficult ethical decisions. Hopefully, this course will assist them with resolving these types of dilemmas.

\section{AACSB Standards Application To Ethical Awareness}

Standard 13 - Individual Faculty Educational Responsibility -

- $\quad$ Operate with integrity in their dealings with students and colleagues.

- $\quad$ Keep knowledge current within their teaching discipline

- Involve students in the learning process

- $\quad$ Encourage collaboration and cooperation and feedback 
Standard 14 - Student Educational Responsibility -

- $\quad$ Operate with integrity in their dealings with students and faculty

- $\quad$ Engage the learning materials with attention

- $\quad$ Maintain their engagement when challenged with difficult material

- $\quad$ Contribute to the learning of others

- $\quad$ Perform to faculty standards

In context of the social contract - that is the expectations of the relationship between business and society, the author applied the social contract between faculty and the students in compliance of AACSB standards 13 and 14 which focus on individual faculty and student responsibilities. In fall of 2004 and 2005, the author surveyed anonymously the business ethics students, at the end of each semester. asking them to assess what their expectations were of the business faculty and what their expectations were for themselves in the role of student $(\mathrm{n}=52)$. An " $\mathrm{S}$ " is noted after each expectation that is similar to the expectation of the faculty of themselves and the students.

The following is a summary of the students' general expectations of faculty:

- $\quad$ expect faculty to be prompt $\mathbf{S}$

- $\quad$ expect faculty to treat all students equally $\mathbf{S}$

- $\quad$ expect faculty to provide an environment that doesn't allow cheating during exams $\mathbf{S}$

- $\quad$ expect faculty to develop new tests on a reasonable basis to reduce cheating among students

- $\quad$ expect faculty to be professional - no sexual harassment, swearing, etc

- $\quad$ expect faculty to be prepared for class $\mathbf{S}$

- $\quad$ expect faculty to grade fairly $\mathbf{S}$

- $\quad$ expect faculty to develop new tests regularly to reduce cheating

The students' ethical expectations of themselves are as follows:

- $\quad$ Do not cheat on exams, assignments, etc $\mathbf{S}$

- $\quad$ Do not plagiarize $\mathbf{S}$

- $\quad$ Attend class on a regular basis $\mathbf{S}$

- $\quad$ Be prompt $\mathbf{S}$

- $\quad$ Do class work as assigned $\mathbf{S}$

- $\quad$ Be respectful to teachers/other students $\mathbf{S}$

- $\quad$ Buy the textbook if required $\mathbf{S}$

In spring semester 2006, the same questions were asked of the Division of Business faculty $(n=10)$. Here is a summary of those responses.

The faculty's expectations of themselves are as follows:

- $\quad$ Be prepared for class $\mathbf{S}$

- $\quad$ Timely arrival to class $\mathbf{S}$

- $\quad$ Maintain office hours

- Have open lines of communication

- $\quad$ Stress ethics in and out of class

- $\quad$ Enjoy teaching - be innovative in class

- $\quad$ Be current in your field

- $\quad$ Present material in a clear manner

- $\quad$ Encourage and treat students with respect $\mathbf{S}$

- $\quad$ Set a good example of behavior -be a role model 
- $\quad$ Prepare students to succeed in a business career

- $\quad$ Have appropriate qualifications for teaching

- $\quad$ Participate in professional development activities

- $\quad$ Be available to help students

- $\quad$ Be in class regularly $\mathbf{S}$

- $\quad$ Return student work in a timely manner

- $\quad$ Be involved in Division and University activities - share the load

- $\quad$ Be involved in the business community

- $\quad$ Do not curve exams more than a few points

- Grade fairly $\mathbf{S}$

Of the 8 listed, there were 5 expectations of the students' expectations of faculty that were similar to the faculties' expectations of themselves. Of the 7 students' expectations of themselves listed, all 7 were identified as an expectation of faculty, although 21 student expectations were listed by faculty. Faculty also identified 21 expectations for themselves.

The faculty's expectations of the students were as follows:

- Demonstrate the ability to solve problems

- Have conceptual clarity

- $\quad$ Be innovative

- Develop comprehension of the material taught

- $\quad$ Be motivated to learn - good learning and study practices

- $\quad$ Follow instructions on syllabus, catalog

- Demonstrate critical thinking skills

- $\quad$ Don't cheat i.e., exams, plagiarize $\mathbf{S}$

- $\quad$ Be respectful of other students/faculty $\mathbf{S}$

- $\quad$ Be prepared for class $\mathbf{S}$

- $\quad$ Participate in class

- $\quad$ Complete assignments professionally and completely $\mathbf{S}$

- $\quad$ Buy the required text and materials for the class $\mathbf{S}$

- $\quad$ Read the text and materials for the class

- $\quad$ Attend class $\mathbf{S}$

- $\quad$ Be prompt $\mathbf{S}$

- $\quad$ Turn in assignments in a timely fashion $\mathbf{S}$

- Develop communication skills

- $\quad$ Develop habits that will transfer to the work force

- $\quad$ Participate in group work as assigned

- $\quad$ Come to instructor for assistance, if needed

This survey provides needed information on the expectations of the relationship between faculty and students. These results were distributed to both the faculty and students in spring semester 2006 and will be integrated into the AACSB action plan in compliance with standards 13 and 14.

Standard 15 - Management of Curricula-Assurance of Learning - Ethical Awareness -

- Use of systematic processes to develop, monitor, evaluate and revise the curricula of degree programs

- $\quad$ Assess the impact of the curricula on learning 


\section{Demonstration Of Learning Achievement}

\section{Course-Embedded Exercises}

Students are required to complete 20 case studies that illustrate the concepts of text. Four case studies are required for each component of the text. The students are also required to analyze the internal and stakeholder analyses of each case study.

Students also complete several team assignments that focus on the principles of each component. These assignments are practical situations that enable the student to apply these concepts to the real world. Additionally, several cases studies are taken from the Wall Street Journal that focus on ethical situations.

Students are required to select a publicly held corporation and analyze its corporate social responsibilities. They are required to assess if they are a good corporate citizen or not and formulate any recommendations to improve their performance. The paper, which is 5-10 pages, is presented to the class at the end of the semester. (Appendix BPaper guidelines)

\section{Objective Testing}

Students are required to complete an objective midterm and final exam that reviews the concepts of the textbook. Each test covers approximately 10 chapters of material.

Students learn in different ways. Some students can demonstrate an assurance of learning from a traditional exam. Other students demonstrate an assurance of learning from written analyses. These different activities provide opportunities to learn and practice a very important aspect of business - ethics and the different learning opportunities provide different avenues for assurance of learning.

\section{ASSESSMENT OF LEARNING RUBRIC}

Five data points to assess students' learning throughout the curriculum were selected including analytical thinking, cultural diversity, technological competence, effective written communication and ethical awareness. The obvious choice, the Business Ethics class, was chosen to assess students' learning of ethical awareness. Based on the activities in the course, a rubric was developed using Bloom's Taxonomy that categorizes knowledge, comprehension, application, analysis and synthesis (Bloom, 1956) (Appendix A). The rubric was applied to the business ethics research paper that have been previously discussed (Appendix B). This exercise was chosen because the paper, due at the end of the semester, provides the student time to incorporate their new knowledge of business ethics. It is also an opportune time to assess their 'ethical awareness' learning level. This rubric was developed in spring semester 2006 and will be first used during the summer semester session 2006.

\section{STUDENTS' ATTITUDE TOWARDS BUSINESS ETHICS EDUCATION}

From an educator's perspective, the author also wanted to determine the students' attitudes towards business ethics education. Did the students feel a business ethics course could have an impact on their ethical behavior in the work environment? In the spring semester 2005, an anonymous survey was distributed to several business classes at Concord University. There were 122 respondents which represent $30 \%$ of those enrolled in business classes during the spring semester.

The focus of the survey was to assess if the students believed if the business ethics course would impact a students' future ethical actions in the workplace. A pretest survey was given to twenty five business students to assess the student's comprehension of the survey questions. Based on their responses, the survey was revised prior to its second implementation. The survey asked the respondents if a business ethics course would impact them in the business world. Additionally, they were asked which business classes included a discussion on business ethics. 


\section{PRELIMINARY SURVEY RESULTS}

Business Students Attitudes towards Business Ethics Education Survey Results Total Sample: 122 actions?

Question: Do you feel the Business Ethics course will help more students in the workplace to assess ethical

\begin{tabular}{|c|c|c|c|c|c|c|c|c|c|}
\hline Yes & $\%$ & No & $\%$ & $\begin{array}{c}\text { No } \\
\text { Difference }\end{array}$ & $\%$ & $\begin{array}{c}\text { No } \\
\text { Response }\end{array}$ & $\%$ & Total & $\%$ \\
\hline 72 & 59 & 16 & 13 & 27 & 22 & 7 & 6 & 122 & 100 \\
\hline
\end{tabular}

Analysis: Nearly $60 \%$ of the respondents indicated the course could assist them with practical ethical situations which is encouraging.

Question: Is business ethics discussed in-depth in other business courses you have taken at this institution?

\begin{tabular}{|c|c|c|c|c|c|c|c|}
\hline Yes & $\%$ & No & $\%$ & $\begin{array}{c}\text { No } \\
\text { Response }\end{array}$ & $\%$ & Total & $\%$ \\
\hline 78 & 63.9 & 41 & 33.6 & 3 & 2.4 & 122 & 100 \\
\hline
\end{tabular}

Analysis: The question's intent was to assess if ethics was discussed in other courses at this institution. Over $60 \%$ indicated there was in-depth discussion.

Which courses?

\begin{tabular}{|l|c|c|c|c|c|c|c|c|}
\hline Course & Yes & $\%$ & No & $\%$ & Nr & $\%$ & Total & $\%$ \\
\hline Principles Of Mgt & 41 & 35.6 & 60 & 52.6 & 11 & 9.6 & 114 & 100 \\
\hline Principles Of Accounting & 25 & 24 & 77 & 74.0 & 20 & 19.2 & 104 & 100 \\
\hline Organizational Behavior & 65 & 59.6 & 41 & 37.6 & 16 & 14.6 & 109 & 100 \\
\hline Entrepreneurship & 11 & 11 & 85 & 85 & 21 & 21 & 100 & 100 \\
\hline Current Topics & 15 & 14.4 & 86 & 82.6 & 21 & 20.1 & 104 & 100 \\
\hline Principles Of Marketing & 18 & 16.9 & 85 & 80.1 & 19 & 17.9 & 106 & 100 \\
\hline Strategic Management & 29 & 29 & 78 & 78 & 0 & 0 & 107 & 100 \\
\hline
\end{tabular}

Analysis: In comparison, it appears that nearly $60 \%$ of those who had taken Organizational Behavior indicated that ethics was discussed in-depth in that course. The remaining of the courses, in the opinion of the students, did not discuss ethics in-depth. This analysis has provided the University's Division of Business a platform to discuss where ethics can be more fully integrated within the curriculum.

\section{CONCLUSION}

One critical finding of the NBES survey is the importance of an ethical culture in organizations which sets the behavioral norms for the employees In 2004, the U.S. Sentencing Guidelines recognized the importance of a ethical culture for compliance (http//www.ethics.org) Although organizations can develop formalized ethical training programs, undergraduate business schools have the opportunity and responsibility to lay the foundation for business students to embrace an ethical environment in the workplace. The AACSB accreditation standards for faculty and student educational responsibility and the assurance of learning standards have provided guidance to ensure that those 
who provide the education and receive the education are encouraged to operate ethically as well which increases the quality of the business education delivery system.

The business ethics survey also provides information about students' attitudes towards business ethics education. The survey's results of their attitudes towards business ethics education was encouraging with nearly $60 \%$ of the students indicating that the course would assist them with dealing with ethical situations in the workplace.

There has been decades of discussion about whether ethics can be taught as a formal education course. An ethics course can be about building awareness to the complexities of the role of a business professional. (Buchanan, 2003, Rivera, 2002, Perry, 1994). At the end of the fall semester 2005, the author asked the students what they learned. Several students indicated that they now realized the importance of corporate social responsibility. Prior to the course, they felt that the only goal of business was to be profitable. Other students stated that the course provided them with the opportunity to reflect on potential unethical situations and how they would handle them in the workforce. These comments indicate that business ethics education may have an impact on students' ethical awareness.

\section{REFERENCES}

1. Bayes, P.E. Compliance with the AACSB's assurance of learning standard: problems and remedial strategies. SEINFORMS annual meeting, Myrtle Beach, South Carolina October 6, 2005.

2. Baue, B. Why is a corporation like a stray cat? An interview with Bob Monks. Business Ethics 19(3): 28-31

3. Bloom, B.S. \& Krathwohl, (1956). D.R. Taxonomy of Educational Objectives: The Classification of Educational Goals, by a committee of college and university examiners. Handbook I: Cognitive Domain. NY: Longmans, Green.

4. Buchanan, B. (2003). Teaching Business Ethics: One School's Notes. Retrieved December 8, 2005 from http://www.singerpubs/ethikos

5. Carroll, A.B., Buchholz, A.K. (2005) Business \& Society: Ethics and StakeholderManagement. Mason,OH: Thomson/Southwestern.

6. CSR: The New Role of Business in Society. Retrieved December 8, 2005 from http://www.uni-boconi.it.

7. Ethics Education in Business Schools: Report of the Ethics Education Task Force to AACSB International's Board of Directors. June 2004

8. Freeman, R.E. (1984). Strategic Management: A Stakeholder Approach. Boston: Pitman Publishing.

9. Mitchell, R.K, Bradley, R.A. \& Wood, D.J. (1997). Toward a theory of stakeholder identification and salience: Defining the principle of who and what really counts. Academy of Management Review, October: 853-886.

10. http://www.aacsb.edu/resource_centers/EthicsEdu. Accessed 12/8/2005

11. Perry, D.L. Can Business Ethics Be Taught? Retrieved December 3, 2005 from http://home.earthlink.net

12. Rivera, R.R \& C. Business ethics 101. Retrieved December 3, 2005 from http://www.boundless.org

13. Fleischer, M, Marek, A. (2005). Press release: National Business Ethics Survey 2005. Retrieved December 9, 2005 from http://www.ethics.org. 


$\begin{gathered}\text { Appendix A Ethical Awareness Assessment of Learning Rubrics } \\ \text { Ethical Awareness }\end{gathered}$
$\begin{array}{ll}\text { Mgt } 430 \text { Business Ethics } \\ \text { Assessment Of Learning } & \text { Faculty } \\ \text { Nate_ } & \text { Title Of Work Research Paper }\end{array}$

1. Identifies Ethical Issues Within A Company Framework

2. Enumerates Consequences Of Unethical Behavior To Stakeholders

3. Propose Solutions To Ethical Problems

4. Develops Evaluation Process For Solutions

The Student Will: Criteria

\begin{tabular}{|l|l|l|l|l|}
\hline \multicolumn{1}{|c|}{ Objectives } & \multicolumn{1}{|c|}{ 1 } & \multicolumn{1}{c|}{$\mathbf{2}$} & \multicolumn{1}{c|}{ 3 } \\
\hline $\begin{array}{l}\text { Identifies Ethical Issues } \\
\text { Within A Company }\end{array}$ & $\begin{array}{l}\text { Not Identify Issues Or } \\
\text { Identification Is } \\
\text { Unintelligible }\end{array}$ & $\begin{array}{l}\text { Correctly Explain The } \\
\text { Issues But Doesn't } \\
\text { Provide In-Depth } \\
\text { Understanding }\end{array}$ & $\begin{array}{l}\text { Correctly Enumerate } \\
\text { Issues But Also Provides } \\
\text { Explanation Of Issues }\end{array}$ \\
\hline $\begin{array}{l}\text { Enumerates Consequences } \\
\text { Of Unethical Behavior To } \\
\text { Stakeholders }\end{array}$ & $\begin{array}{l}\text { Not List Or Those Listed } \\
\text { Do Not Relate To The } \\
\text { Ethical Issue }\end{array}$ & $\begin{array}{l}\text { Enumerates 1-2 } \\
\text { Consequences Only }\end{array}$ & $\begin{array}{l}\text { Enumerates All } \\
\text { Consequences Of } \\
\text { Behavior Discussed In } \\
\text { Class }\end{array}$ \\
\hline $\begin{array}{l}\text { Proposes } \\
\text { Recommendations To } \\
\text { Resolve Ethical Problems }\end{array}$ & $\begin{array}{l}\text { Identify } \\
\text { Recommendations That } \\
\text { Demonstrate Minimal } \\
\text { Comprehension Of The } \\
\text { Ethical Problem } \\
\text { Resolution }\end{array}$ & $\begin{array}{l}\text { Explain } \\
\text { Recommendations That } \\
\text { Demonstrate A Basic } \\
\text { Comprehension Of The } \\
\text { Ethical Problem } \\
\text { Resolution }\end{array}$ & $\begin{array}{l}\text { Differentiate } \\
\text { Recommendations That } \\
\text { Demonstrate An In Depth } \\
\text { Comprehension Of The } \\
\text { Ethical Problem } \\
\text { Resolution }\end{array}$ \\
\hline $\begin{array}{l}\text { Develops Evaluation } \\
\text { Process For } \\
\text { Recommendations }\end{array}$ & $\begin{array}{l}\text { Identify Evaluations Of } \\
\text { Recommendations That } \\
\text { Demonstrate A Minimal } \\
\text { Comprehension Of The } \\
\text { Problem Resolution }\end{array}$ & $\begin{array}{l}\text { Outline Evaluations Of } \\
\text { Recommendations That } \\
\text { Demonstrate A Basic } \\
\text { Comprehension Of The } \\
\text { Problem Resolution }\end{array}$ & $\begin{array}{l}\text { Categorize Evaluations Of } \\
\text { Recommendations That } \\
\text { Demonstrate An In Depth } \\
\text { Comprehension Of The } \\
\text { Problem Resolution }\end{array}$ \\
\hline Total Points & \multicolumn{2}{l}{} & \\
\hline
\end{tabular}

\title{
Appendix B - Business Ethics Paper Guidelines
}

\author{
MGT 430 \\ Business Ethics \\ Research Paper \\ Guidelines \\ Length - 5-10 pages \\ Citations - 10 unique
}

All sources need to be cited and included in the appropriate format at the end of the paper. Your paper must be submitted to www.turnitin.com

Thesis: Select a company that is being a good corporate citizen or is not. By using information provided in the text, analyze the company's policies. You can use their website, reports, media, etc to support your thesis.

You can analyze their commitment to their internal and external stakeholders. You can look at their marketing operations, corporate social performance, special interest groups, etc to support your thesis.

Based on your analysis, develop recommendations to improve their corporate performance. 